\section{Haemorrhagic vesicles and varioliform scarring: consider photosensitivity}

A 6-year-old boy presented with a 2-year history of recurrent episodes of painful, haemorrhagic vesicles and erythema affecting the face, ears and neck, 2 hours after sun exposure (figures 1 and 2). He had severe ulceration and crusting affecting the helix of his ear (figure 3). Healing was accompanied by residual varioliform, atrophic scarring (figure 4). His rash occurred during spring and summer months and only affected sun-exposed sites.

$\mathrm{He}$ was referred for investigation in a photodermatology unit, which showed positive provocation of his rash with broadband ultraviolet (UV) radiation and reduced phototest thresholds at $350-370 \mathrm{~nm}$ wavelengths, confirming the presence of UVA photosensitivity. Epstein-Barr virus (EBV) IgG was positive. His connective tissue disease and porphyria screens were negative.

Hydroa vacciniforme is a photosensitivity disorder of childhood of unknown aetiology which leads to painful vesicular eruptions affecting sun-exposed sites, settling with haemorrhagic crusting. It tends to resolve in adolescence but can leave permanent pox-like, depressed scarring. An association has been found between hydroa vacciniforme and latent EBV infection. ${ }^{1}$ Management includes careful photoprotection with broad-spectrum sunscreens, sun-protective clothing and UV films for windows. Regular vitamin D replacement should be offered. Appropriate urgent referral is vital to improve quality of life and to minimise scarring.

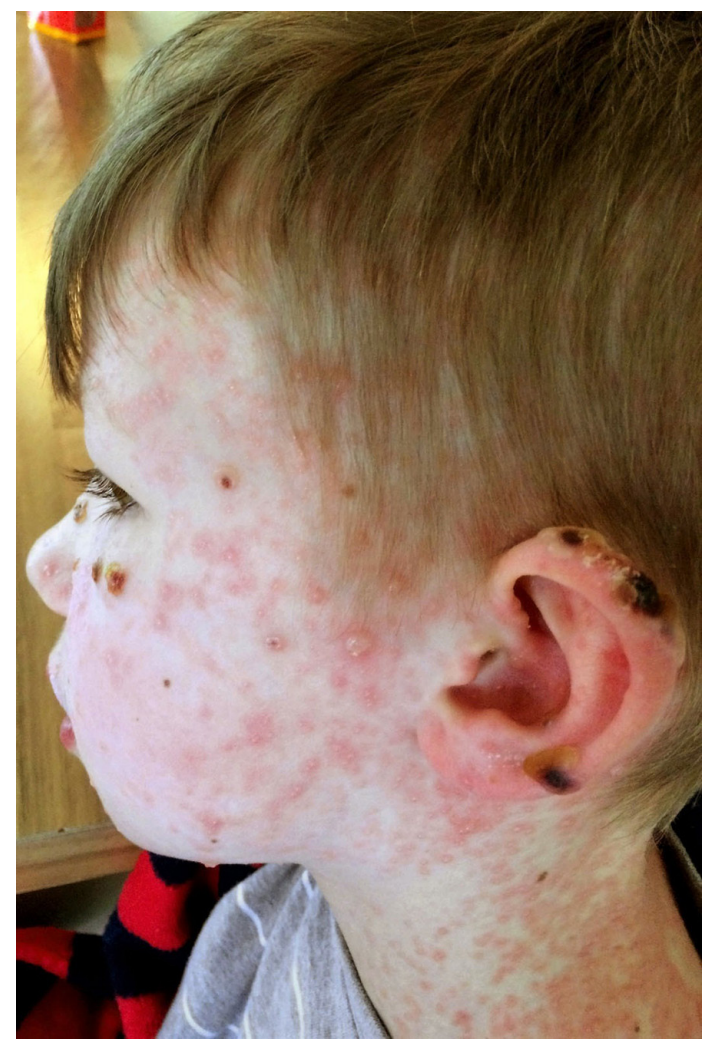

Figure 1 Tender erythematous vesicles and papules with haemorrhage and crusting arising 2 hours after sun exposure.

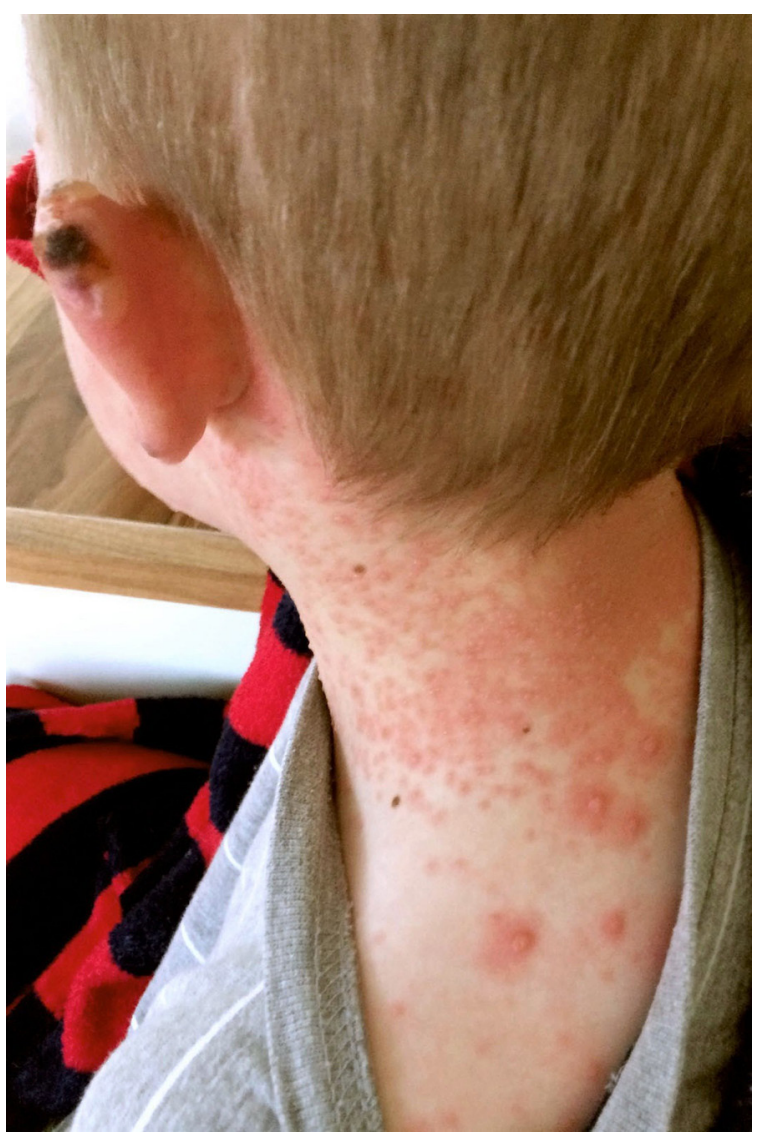

Figure 2 Tender erythematous vesicles and papules with haemorrhage and crusting arising 2 hours after sun exposure.

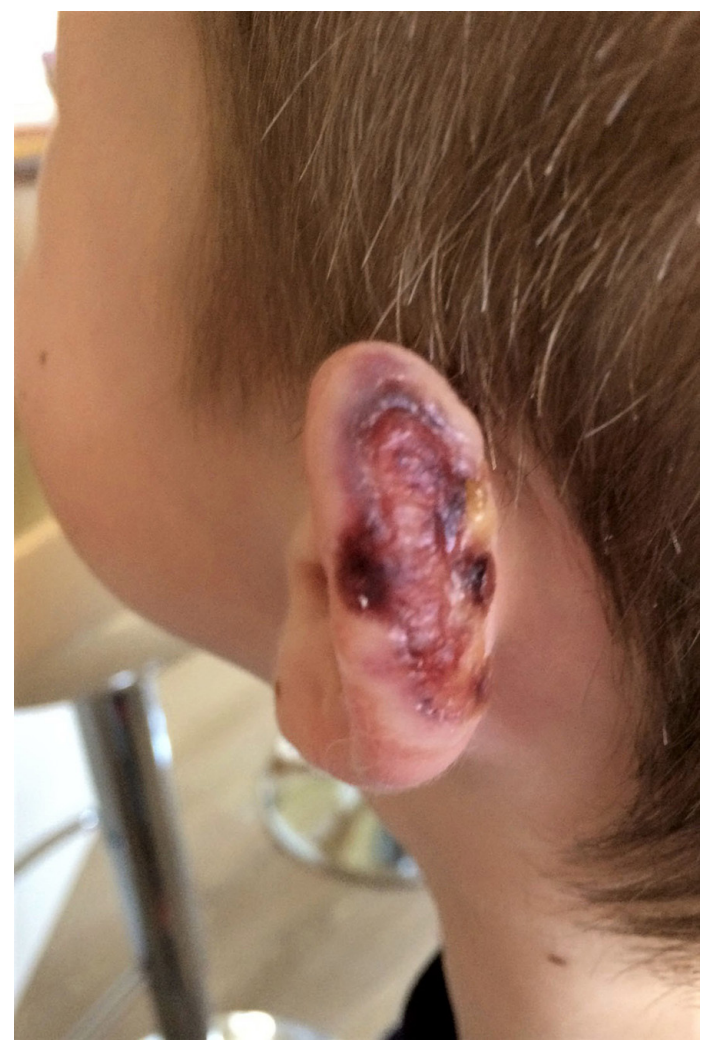

Figure 3 Severe ulceration and crusting affecting the helix of his ear. 


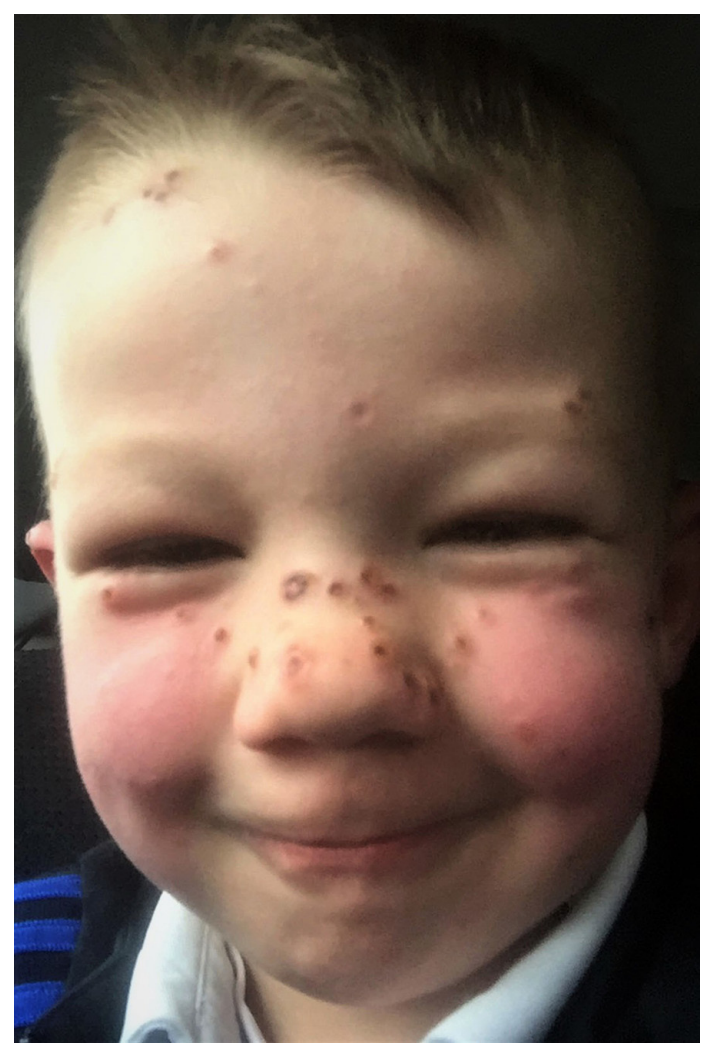

Figure 4 Resolving eruption and residual varioliform, atrophic scarring.

Tashmeeta Ahad $\odot,{ }^{1}$ Lesley E Rhodes ${ }^{1,2}$

Department of Dermatology, Salford Royal NHS Foundation Trust, Manchester, UK ${ }^{2}$ Division of Musculoskeletal and Dermatological Sciences, University of Manchester, Manchester, UK
Correspondence to Dr Tashmeeta Ahad, Department of Dermatology, Salford Royal Hospital, Manchester M6 8HD, UK; tashmeeta@gmail.com

Contributors The manuscript was written by TA. LER contributed to critical revision of the manuscript.

Funding The authors have not declared a specific grant for this research from any funding agency in the public, commercial or not-for-profit sectors.

Competing interests None declared.

Patient consent Parental/guardian consent obtained.

Provenance and peer review Not commissioned; internally peer reviewed.

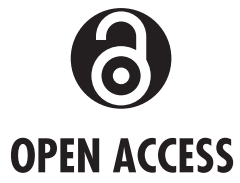

Open access This is an open access article distributed in accordance with the Creative Commons Attribution Non Commercial (CC BY-NC 4.0) license, which permits others to distribute, remix, adapt, build upon this work non-commercially, and license their derivative works on different terms, provided the original work is properly cited, appropriate credit is given, any changes made indicated, and the use is non-commercial. See: http://creativecommons.org/licenses/by-nc/4.0/.

(C) Author(s) (or their employer(s)) 2020. Re-use permitted under CC BY-NC. No commercial re-use. See rights and permissions. Published by BMJ.

A) Check for updates

To cite Ahad T, Rhodes LE. Arch Dis Child 2020;105:300-301.

Accepted 30 October 2018

Published Online First 13 November 2018

Arch Dis Child 2020;105:300-301. doi:10.1136/archdischild-2018-316272

ORCID iD

Tashmeeta Ahad http://orcid.org/0000-0002-0061-6011

\section{REFERENCE}

1 Bolognia JL, Schaffer JV, Cerroni L. Dermatology: 2-Volume Set, 4e: Elsevier. 